\title{
A SYSTEMS APPROACH TO OPERATIONAL AND BUSINESS DECISION-MAKING
}

\author{
P.J. Pretorius ${ }^{1 *}$
}

\section{ARTICLE INFO}

Article details

Presented at the $30^{\text {th }}$ annual conference of the Southern African Institute for Industrial Engineering (SAIIE), held from 30 September - 2 October 2019 in Port Elizabeth, South Africa

Available online

15 Nov 2019

\section{Contact details \\ Corresponding author \\ beheng.pjp@gmail.com}

Author affiliations

1 Independent Educator and Consultant

DOI

http://dx.doi.org/10.7166/30-3-2228
The "PQ" problem was published in 1990 by Goldratt. An adapted version of this problem is provided to master's level students a few weeks before starting an operations management course. The performance statistics collected from three South African (since 2016) and one European business school (from 2018 onwards) do not make for good reading. To date, only 2.3 per cent of the students (42 students from the sample of 1866 students) were able to answer both questions correctly; and some of them were not able to justify their correct decisions. This paper will explore the differences between traditional, cost-based methods of decision-making for day-to-day operational and improvement decisions as practised by many companies today - and hence the bad performance by the students - and taking a systems approach to decision-making. The paper will argue for taking the systems approach as a real alternative, without which alternative realities will remain but a dream.

\section{OPSOMMING}

Die "PQ" probleem is in 1990 deur Goldratt gepubliseer. 'n Aangepaste weergawe van hierdie probleem word aan meestervlak studente gegee ' $n$ paar weke voor die aanvang van 'n kursus in operasionele bestuur. Die prestasie-statistiek ingesamel by drie Suid-Afrikaanse (sedert 2016) en een Europese besigheidskool (sedert 2018) is onrusbarend swak. Tot op hede, was slegs 2.3 persent van die studente (42 studente uit die steekproef van 1866 studente) in staat om beide vrae korrek te beantwoord, en van hulle was nie in staat om hulle korrekte antwoorde te verduidelik nie. Hierdie artikel ondersoek die verskille tussen tradisionele, kostegebaseerde metodes van besluitneming vir dag-tot-dag operasionele- en verbeteringsbesluite soos deur verskeie ondernemings vandag gebruik word - en daarom die swak studenteprestasie - en ' $n$ stelselbenadering tot besluitneming. Hierdie artikel voer aan dat 'n stelselbenadering ' $n$ werklike alternatief is tot besluitneming, waarsonder alternatiewe werklikhede bloot 'n droom sal bly.

\section{INTRODUCTION}

When meeting my master's level students in class for their first session, we have a short discussion on what management is. The conclusion that we come to is that management is about making and implementing decisions to better achieve the goal of the organisation and about taking responsibility for the decisions and their outcomes. We also conclude that management is therefore oriented towards an uncertain future - unlike financial accounting, which records a known past. When asked what managers spend most of their time on every day, the most frequent answer is 'meetings'. My follow-on question, naturally, must be: "What is discussed in those meetings?" The answer is generally that the discussions revolve around things that have gone wrong (i.e., reactive) - in other words, the future arrived differently from what was planned (i.e., what decisions were made). When asked about whether time is spent on planning and future improvements (i.e., being pro-active), 
the response is somewhat less enthusiastic. When asked what the split is between the reactive and pro-active time spent, it is generally in the order of 80:20 in favour of reactive time, with some even suggesting that it might be closer to a 90:10 split. The conclusion that is then reached is that managers tend to spend most of their time trying to deal with uncertainty and variability, either reactively or pro-actively. The next question stretches the imagination: If we could totally eliminate uncertainty and variability, would management be difficult or easy? Obviously, if we spend so much time on uncertainty and variability, it must be our biggest problem in achieving organisational goals. If uncertainty and variability were removed, it would make our lives so much easier and, according to many of the students, management would tend to become easy - even boring.

An operational system producing two products, using four resources in eight processes, and four raw materials, does not constitute a complex system. In addition, removing all variability and uncertainty in the raw material supply, internal processing and market demand simplify it even more. Selling prices, demand, and variable and fixed costs are provided. Two questions are thus posed:

1. Which is the most profitable product for this operational system?

2. Given the detail provided for the two improvement proposals, which of the two proposals, or neither, or both, should be implemented?

The problem described above is an adaptation of the "PQ" problem published by Goldratt [1] in 1990. The adapted "PQ" problem, with related information, is shown in Figure 1 and Table 1 . The detail of the questions is provided in Table 2 . This is the problem with which my students - most of them employed at middle to higher management levels - are provided a few weeks before starting a master's level course on operations management. With the quality of these students (many of them engineering graduates), one expects good results.

It is at this stage of the discussion that I remind my students that they have been exposed to a an ideal organisation in their preparation leading up to the contact sessions. Many of them would have forgotten about this, since it is required as a first preparation exercise. Logic dictates that, if uncertainty and variability are our biggest problem in achieving organisational goals, when we remove them (as in the posed, adapted "PQ" problem), then most students must arrive at the same correct answer. It is at this point that I first reveal the statistics on how well (or badly) they have performed. The performance statistics collected since 2016 from three South African and one European business school do not make for good reading. To date, only 2.3 per cent of students (42 students from the sample of 1866 students - shown in Table 3) were able to answer both questions correctly; and some of the students who provided the correct answers were not able to justify their correct decisions.

It must now be obvious that uncertainty and variability are not our biggest problem. These results raise the question, "Why are the results so abysmal?" There must be a reason, other than uncertainty and variability, that prevents good decision-making. Considering the fact that the average age of the students is in the low thirties, and most of them have been in management positions for some years, one cannot cite lack of experience as the reason.

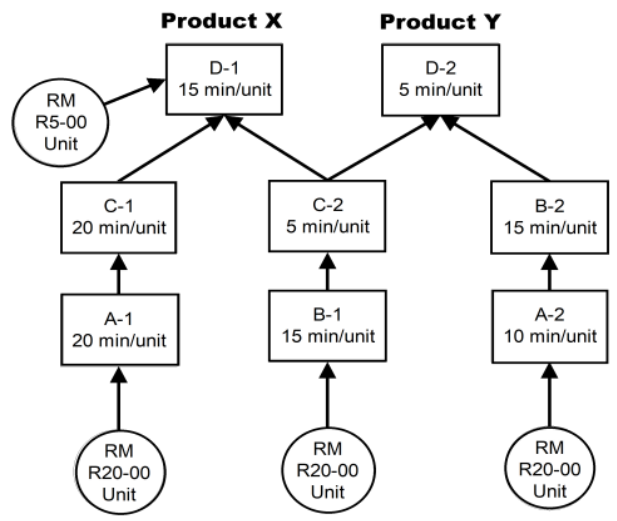

\begin{tabular}{|l|c|c|}
\cline { 2 - 3 } \multicolumn{1}{c|}{} & $\begin{array}{c}\text { Demand/ } \\
\text { week }\end{array}$ & $\begin{array}{c}\text { Selling } \\
\text { price/unit }\end{array}$ \\
\hline Product $X$ & 60 & $\mathrm{R} 95.00$ \\
\hline Product $Y$ & 60 & $\mathrm{R} 105.00$ \\
\hline
\end{tabular}

1. One of each resource; cannot substitute for each other

2. Each resource available for 2400 minutes per week

3. Fixed cost is R6 000-00 per week or R1 500-00 per resource per week

Figure 1: The basic layout and information for the adapted "PQ" problem [1] 
XY Enterprises runs in a perfect business environment. That means that Murphy does not exist (i.e., there is no uncertainty, no unexpected, negative events; nothing can or will go wrong). Everything is known exactly, and no deviation from the known numbers occurs.

The demand for the products (as shown to the left of Figure 1) is constant - i.e., the demand does not increase or decrease over time. The selling prices charged are at an optimum, as a one cent increase in either of the selling prices will cause the demand for both products to drop to zero. Also, if the selling price of any product is reduced, the volume demanded will stay exactly the same.

The process dependency diagram (to the right of Figure 1) indicates the tasks and resources required to deliver Products $X$ and $Y$. The following information is available:

1. There is one of each resource A, B, C, and D (in other words, there are four resources doing the work); each resource performs two tasks (e.g., resource A performs tasks A-1 and A-2). A resource can only work on one task at a time - i.e., working on more than one task at the same time is not possible. However, a resource does not lose any time when switching over from one task to another. Resources cannot substitute for each other.

2. Each resource is available to work for 2400 minutes per week. (No delays, no strikes, no setups, no public holidays!)

3. Fixed cost is R1 500.00 per resource per week or R6 000.00 total cost per week.

4. There are no other overhead costs.

5. Raw material (RM) supply is instantaneous (zero lead time), and both the quality and quantity are perfect. The supplier will not raise the price of raw material at any time.

6. The raw material for process B-1, Process B-1 itself, and Process C-2 are required for both products. If one of Product $X$ and one of Product $Y$ are required, then process $B-1$ and $C-2$ must be executed twice, and twice the raw material will be required.

7. Task times are constant (there is no task-time variation).

Table 2: Questions to be answered about the adapted "PQ" case [1]

Which one of the two products, $X$ or $Y$, is the most profitable product for $X Y$ Enterprises? For the purpose of voting, select one of the following options on the LMS ${ }^{1}$ voting page:

1) The two products are equally profitable for $X Y$ Enterprises

2) Neither of the two products is profitable for $X Y$ Enterprises

3) Product $X$ is the most profitable product for $X Y$ Enterprises

4) Product $Y$ is the most profitable product for $X Y$ Enterprises

Two consultants have been tasked to improve the productivity of the resources responsible for the tasks to produce Products $X$ and $Y$. After devoting time to this, they each come up with a project proposal.

The first consultant's project proposal (Proposal 1)

Change task C-2 to take 8 (eight) minutes instead of it taking 5 (five) minutes. Change task B-1 to take 14 (fourteen) minutes instead of 15 (fifteen) minutes. Total task time of the center section will thus increase from 20 (twenty) to 22 (twenty-two) minutes. Total cost to implement the change will be a once-off R5 000.00. All this will be done without compromising quality! Everything else stays the same.

The second consultant's proposal (Proposal 2)

Reduce the task times of task $C-1$ and $A$ - 1 in the left-hand section to take 5 (five) minutes for task $A$ - 1 and 15 (fifteen) minutes for task C-1. Total task time of the left-hand section is reduced from 40 (forty) to 20 (twenty) minutes. At the same time in the right-hand section, the task time on task A-2 is reduced to 5 (five) minutes. Total task time in the right-hand section is reduced from 25 (twenty-five) to 20 (twenty) minutes. Total cost to implement the change will be a once-off $R 3000.00$. This will also be done without compromising quality! Everything else stays the same.

Which one of the two proposals will you implement? You also have the option of implementing both or neither of the two. You must be able to justify your answer in class.

For the purpose of voting, select one of the following options on the LMS voting page:

1) Implement both project Proposal 1 and project Proposal 2

2) Do not implement any of the project proposals

3) Only implement project Proposal 1

4) Only implement project Proposal 2

1 In all cases, learning management systems (LMS) were used to collect the student answers electronically. 
Table 3: Performance statistics of student answers for the adapted "PQ" problem

\begin{tabular}{|c|c|c|c|c|c|}
\hline Year & Group & Number of students & Correct product & Correct proposal & Both correct \\
\hline 2016 & Group 1 & 26 & 1 & 3 & 1 \\
\hline 2016 & Group 2 & 25 & 3 & 5 & 1 \\
\hline 2016 & Group 3 & 19 & 1 & 0 & 0 \\
\hline 2016 & Group 4 & 54 & 5 & 4 & 2 \\
\hline 2016 & Group 5 & 68 & 8 & 7 & 1 \\
\hline 2016 & Group 6 & 66 & 5 & 5 & 1 \\
\hline 2016 & Group 7 & 65 & 7 & 8 & 2 \\
\hline 2016 & Group 8 & 57 & 7 & 5 & 1 \\
\hline 2016 & Group 9 & 20 & 0 & 0 & 0 \\
\hline 2017 & Group 1 & 59 & 8 & 11 & 4 \\
\hline 2017 & Group 2 & 33 & 6 & 5 & 3 \\
\hline 2017 & Group 3 & 73 & 3 & 4 & 1 \\
\hline 2017 & Group 4 & 75 & 2 & 4 & 0 \\
\hline 2017 & Group 5 & 75 & 10 & 6 & 2 \\
\hline 2017 & Group 6 & 67 & 8 & 8 & 3 \\
\hline 2018 & Group 1 & 101 & 4 & 16 & 0 \\
\hline 2018 & Group 2 & 67 & 11 & 8 & 2 \\
\hline 2018 & Group 3 & 32 & 5 & 5 & 1 \\
\hline 2018 & Group 4 & 74 & 5 & 6 & 1 \\
\hline 2018 & Group 5 & 75 & 3 & 8 & 1 \\
\hline 2018 & Group 6 & 72 & 3 & 5 & 0 \\
\hline 2018 & Group 7 & 65 & 6 & 6 & 1 \\
\hline 2018 & Group 8 & 76 & 10 & 13 & 4 \\
\hline 2019 & Group 1 & 137 & 6 & 24 & 2 \\
\hline 2019 & Group 2 & 32 & 0 & 2 & 0 \\
\hline 2019 & Group 3 & 68 & 8 & 9 & 4 \\
\hline 2019 & Group 4 & 68 & 3 & 6 & 1 \\
\hline 2019 & Group 5 & 66 & 6 & 5 & 1 \\
\hline 2019 & Group 6 & 20 & 1 & 0 & 0 \\
\hline 2019 & Group 7 & 63 & 5 & 9 & 2 \\
\hline 2019 & Group 8 & 68 & 7 & 13 & 0 \\
\hline \multicolumn{2}{|c|}{ Totals } & 1866 & 157 & 210 & 42 \\
\hline \multicolumn{3}{|c|}{ Percentage } & $8.4 \%$ & $11.3 \%$ & $2.3 \%$ \\
\hline
\end{tabular}

\section{THE WRONG WAY AND THE RIGHT WAY}

\subsection{Looking at the problem the traditional way}

Drucker [2] made the following observation about how companies are often managed:

Costs - their identification, measurement and control - are the most thoroughly worked, if not overworked, business area. The annual cost-reduction drive is as predictable in most businesses as a head cold in spring. It is about as enjoyable. But six months later costs are back where they were - and business braces itself for the next cost-reduction drive.

Despite being a very old quote, it still seems to be the predominant approach employed by many companies today, making cost reduction their number one focus.

Cost per unit is a prime measurement in most companies, to the extent that Smith and Smith [3] call it a deep truth:

That deep truth is the assumption that return on investment (ROI) is maximized through and directly corresponds to the minimization of unit cost.

Many methods exist where fixed costs are allocated to products, together with variable costs, to arrive at a unit cost or cost-per-unit. Most notably, activity-based costing (ABC), as advocated by Cooper and Kaplan [4], is a very popular method. They argue that there is a hierarchy of operational expenses, and that a clear distinction should be made about the level on which an activity drives 
cost. The levels they advocate are unit level activities (consisting of direct labour, materials, machine, and energy costs), batch level activities (setups, material movements, purchase orders, and inspection), product sustaining activities, and facility sustaining activities. They correctly argue that any cost not on the unit level should not be allocated to the unit level, since any cost above the unit level allocated might give the wrong impression - that those costs vary with the number of units. The "PQ" problem is ideally suited to eliminate wrong cost allocations above the unit level (as per the $A B C$ view), since the "PQ" problem only has unit level costs (i.e., direct labour and material costs; not even machine and energy costs), and no higher-level batch, product- or facility sustaining activity costs.

The $A B C$ analysis that follows is exactly the same as the $A B C$ analysis performed by Gupta and Baxendale [5], except that the numbers for the adapted "PQ" problem as shown in Figure 1 are used. To answer the first question, an $A B C$ analysis is performed on each of the two products, as shown in Table 4, and as previously shown by Pretorius [6].

Table 4: $A B C$ analysis to determine profitability of each of the two products

\begin{tabular}{|c|c|c|}
\hline & Product X & Product $Y$ \\
\hline Selling price & R95.00/unit & R105.00/unit \\
\hline Material (variable) cost & R45.00/unit & R40.00/unit \\
\hline Activity required & $75 \mathrm{~min} /$ unit & $50 \mathrm{~min} /$ unit \\
\hline Minute rate $^{a}$ & $\mathrm{R} 0.625 / \mathrm{min}$ & $\mathrm{R} 0.625 / \mathrm{min}$ \\
\hline Product cost & R91.875/unit & R71.25/unit ${ }^{\mathrm{C}}$ \\
\hline Product profit $^{\mathrm{d}}$ & R3.125/unit & R33.75/unit \\
\hline
\end{tabular}

a Resources are paid equally; therefore the minute rate is the same for $A, B, C$, and D, i.e. R1500/2400 = R0.625/minute.

b Product cost for $\mathrm{X}$ was calculated as (activity minutes required $\mathrm{x}$ minute rate) plus variable cost - i.e., (75 mins $\times$ R0.625/min) + R45.00 = R91.875.

c Product cost for $Y$ was calculated as (activity minutes required $x$ minute rate) plus variable cost - i.e., (50 mins $\times$ R0.625/min) + R40 $=$ R71.25

d $\quad$ Product profit $=$ Selling price - product cost

Most students, when attempting question 1, will choose the answer that $Y$ is more profitable than $X$, using the $A B C$ method. Not many of them do the calculation shown in Table 4; rather, they use logic: since the selling price of $Y$ is more than $X$, the variable cost of $Y$ is less than $X$, and the time (activities) required to make $Y$ is less than that of $X$, it must be concluded that $Y$ is more profitable than $X$. The first underlying assumption made is that 'time is money', which is part of the $A B C$ thinking.

To answer the second question, an $A B C$ analysis is performed on each of the two products to consider the changes proposed and shown in Table 5, as previously shown by Pretorius [7].

Table 5: $A B C$ analysis to determine viability of each of the two proposals

\begin{tabular}{|l|r|r|}
\cline { 2 - 3 } \multicolumn{1}{c|}{} & Product X & Product $\mathrm{Y}$ \\
\hline Selling price & $\mathrm{R} 95.00 /$ unit & $\mathrm{R} 105.00 /$ unit \\
\hline Material (variable) cost & $\mathrm{R} 45.00 /$ unit & $\mathrm{R} 40.00 /$ unit \\
\hline Proposal 1 & & \\
\hline Activity required & 77 min/unit & 52 min/unit \\
\hline Product cost & $\mathrm{R} 93.125 /$ unit & $\mathrm{R} 72.50 /$ unit \\
\hline Product profit & $\mathrm{R} 1.875 /$ unit & $\mathrm{R} 32.50 /$ unit \\
\hline Product profit change & $-\mathrm{R} 1.25 /$ unit & $-\mathrm{R} 1.25 /$ unit \\
\hline Proposal 2 & & \\
\hline Activity required & 50 min/unit & 45 min/unit \\
\hline Product cost & $\mathrm{R} 76.25 /$ unit & R68.125/unit \\
\hline Product profit & $\mathrm{R} 18.75 /$ unit & $\mathrm{R} 36.875 /$ unit \\
\hline Product profit change & $\mathrm{R} 15.625 /$ unit & $\mathrm{R} 3.125 /$ unit \\
\hline
\end{tabular}

Most students, when attempting question 2, will choose the answer that Proposal 2 should be implemented rather than Proposal 1 . Not many of them do the calculation shown in Table 5, but rather rely on the underlying assumption that 'time is money' - i.e., a reduction in time is always beneficial and more cost-effective.

At first glance, both answers seem to be correct and based on sound logic. However, both are horribly wrong. 


\subsection{Looking at the problem the systems way}

Whenever one reads an article about the future, the same message seems to permeate all of them: the future will entail more complexity, more change, more competition, and more chaos. In the face of this, many solutions fail because they simply are not holistic and do not consider the systemic nature of the world within which we live. Since organisations are systems, we have no choice but to view our organisations as systems - even those with such little complexity (and no uncertainty) as the adapted "PQ" problem.

A fundamental system principle is that each system is constrained and has at least one constraint. According to Noreen, Smith and Mackey [8]:

The core idea in TOC [systems thinking] is that every real system such as a profit-making enterprise must have at least one constraint. If it were not true, then the system would produce an infinite amount of whatever it strives for. In the case of a profit-making enterprise, it would be infinite profits. Because a constraint is a factor that limits the system from getting more of whatever it strives for, then a business manager who wants more profits must manage the constraints. There really is no choice in the matter. Either you manage constraints or they manage you. The constraints will determine the output of the system whether they are acknowledged and managed or not.

In order to approach the adapted "PQ" problem, one must first ask where the constraint is for the organisation. A basic calculation can be made to determine whether the organisation has sufficient capacity to meet demand, which will denote a market constraint; or whether the organisation cannot meet the market demand, which will indicate an internal constraint. The calculation is shown in Table 6.

Table 6: Resource loads to determine constraint location

\begin{tabular}{|c|c|c|c|c|}
\hline Resource & $\begin{array}{c}\text { Product } \\
\text { X }\end{array}$ & $\begin{array}{c}\text { Product } \\
\text { Y }\end{array}$ & $\begin{array}{c}\text { Total mins } \\
\text { rqrd/week }\end{array}$ & $\begin{array}{c}\text { Mins/week } \\
\text { available }\end{array}$ \\
\hline A & $60(20)$ & $60(10)$ & 1800 & 2400 \\
\hline B & $60(15)$ & $60(30)$ & 2700 & 2400 \\
\hline C & $60(25)$ & $60(5)$ & 1800 & 2400 \\
\hline D & $60(15)$ & $60(5)$ & 1200 & 2400 \\
\hline
\end{tabular}

From the above calculation, it is clear that an internal constraint exists, and that the full demand for the two products cannot be met. This obviously now requires a decision about which product to maximise, and which product needs to have its quantity reduced.

The correct way to determine the profitability of products when an internal constraint exists is a concept that has been known for a very long time. Even though it exists in management accounting textbooks, very few students are familiar with it, or they just tend to forget it. This is despite the fact that most students have completed a course in management accounting not long before starting the course on operations management. The first quote by Horngren [9] dates back to 1981, and the second by Drury [10] is as recent as 2013 (and is very clumsily expressed, almost as if it were a deliberate attempt to create confusion):

The product to be pushed or the order to be accepted is the one that makes the biggest total profit contribution per unit of the limiting factor. [9]

Where limiting factors apply, profit is maximized when greatest possible contribution to profit is obtained each time the scarce or limiting factor is used. [10]

The rate of product profit generation is calculated by taking the contribution margin of the product divided by the time the product spends on the constraint. Fixed cost is ignored, since it is irrelevant to the mix decision - another known management accounting principle. The calculation is shown in Table 7.

From the above calculation, Product $X$ is more profitable than $Y$, since it generates profits (i.e., contributions) faster than Product $Y$. The focus is thus truly on profitability and not cost. 
Table 7: Profitability calculation considering the internal constraint

\begin{tabular}{|l|r|r|}
\cline { 2 - 3 } \multicolumn{1}{c|}{} & Product X & Product Y \\
\hline Selling price & R95.00/unit & R105.00/unit \\
\hline Material (variable) cost & R45.00/unit & R40.00/unit \\
\hline Contribution margin & R50/unit & R65/unit \\
\hline Constraint time & 15 min/unit & 30 min/unit \\
\hline Throughput rate & R3.33/constraint min & R2.17/constraint min \\
\hline
\end{tabular}

Analysing the two proposals, while considering the existence of an internal constraint, suddenly changes the whole method of analysis. Logic would be sufficient to eliminate Proposal 2 immediately. The reason is that a once-off cost payment would increase overall fixed costs (by R3 000 once-off), despite the fact that the cost per unit has gone down as calculated in Table 5. In addition, since the constraint resource determines how many units can be produced and sold, along with the realisation that Proposal 2 does not increase capacity on the constraint, not a single unit more will be produced and sold. Therefore, the inevitable conclusion is that the profit of the organisation, along with its return on investment (ROI) and cash flow (CF), will go down, and that Proposal 2 should not even be considered - i.e., the opposite decision to the one the $A B C$ approach suggests. See the discussion section for a further explanation of the logic.

Proposal 1, one the other hand, reduces the time on the constraint, which suggests that it will be possible to produce and sell more units for which there is still a demand. Whether it is worthwhile in the long run, considering the implementation costs and the increase in load on Resource $C$, must be considered by making a calculation to prove or disprove the viability. This calculation will be provided in the discussion section.

\section{3}

DISCUSSION

\subsection{The goal and goal measurement}

Goldratt [1] has been quoted ad nauseam on what the goal is; and at the expense of repeating a cliché, here it is again:

The goal of a for-profit company is to make more money now as well as in the future.

Once the goal is clearly articulated, it is necessary to define the measurements that will indicate whether the goal is achieved or not. It does not take a rocket scientist to derive the correct measurements. The absolute measurement is net profit (NP), whereas return on investment (ROI) is the relative measurement. In other words, ROI indicates how well you are making profit relative to the amount invested. There is also a necessary condition (not a measurement) which is cash flow, and which is necessary for survival. By having an income statement, a balance sheet and a cash flow statement, it seems as if the accounting system indicates exactly how these two metrics support goal achievement while meeting the necessary condition. This is however where the real problem starts. The way the financial statements are legally required to be set up, allows for manipulation of the accounting system [11] to make the numbers (NP and ROI) look good. At the same time, when decisions are made to make the accounting numbers look good, cash flow may be jeopardised, and profits may not improve. This is because management is making decisions about the future (to better achieve the organisational goal and heavily reliant on judging the impact of a management decision on NP, ROI and cash flow simultaneously), whereas accounting is about recording the past (setting up the income statement and balance sheet to satisfy regulatory requirements and shareholder expectations), but having no real impact on cash flow from an accounting perspective. But meeting the regulatory requirements does not mean the goal is better achieved. Cooper and Kaplan [4] correctly state that:

The gross numbers on corporate financial statements reflect the decisions made and actions taken throughout the business. They represent the aggregation of thousands of small stories about how the company designed, produced, and delivered its products, served customers, and developed and maintained brands. But this kind of income report won't help managers decide what to do to improve the numbers for next year's financial statement.

The 'thousands of small stories' no doubt refer to previous decisions being made that now show up to make the financial statements look good. It is therefore logical to conclude that historical 
financial statements cannot guide decisions about the future, since the goals and the logic of financial accounting and decision making fundamentally differ. Furthermore, accounting is concerned with the last period income statement and balance sheet; decision making is about future $\mathrm{NP}, \mathrm{ROI}$ and cash flow (irrespective of how these will be recorded in future). A major problem, however, is that many decisions made to make the financial statements look good are actually devastating.

We are all too familiar with net profit, ROI, and cash flow. After all, these are addressed when we look at our financial accounting systems. The problem lies in the word 'accounting', which suggests the process of a recording of financial expenditure and receipts relating to a particular [past] period or purpose. It is clear that accounting deals with the past. The nature of recording the past - i.e., writing up the financial history - requires accuracy, and is closely regulated by accounting rules such as the Generally Accepted Accounting Principles (GAAP) or the International Financial Reporting Standards (IFRS) of the Financial Accounting Standards Board (FASB) to ensure the accuracy of the records.

Both IFRS and GAAP mandate the use of accrual method for recording all revenue and expenses. The accrual accounting concept is rooted in [the] matching principle. So, if a business earns money in 2013, it will be recorded as sales for 2013, even if the payments for this sale are expected to be received only in 2014. The accrual accounting system is very flexible and provides the management many opportunities to manipulate their financial statements. [11]

It also follows that the costs associated with inventory/work done in one financial year are not necessarily accounted for in the year in which they were actually incurred, but in the year the selling transaction of the goods/work took place. The problem is that, even though you are able to record the actual financial events accurately, these systems, by allowing this 'flexibility', open up the opportunity to manipulate the financial statements from a timing perspective. Due to the backward looking/historical nature of financial accounting, it is not suitable to make management decisions about the future.

It might be argued that there is a different discipline to financial accounting, that of management accounting, which is supposed to deal with decisions about the future. There is, however, a big anomaly in the phrase 'management accounting'. We know that management is dealing with the future, which requires relevant, albeit inaccurate, data. Accounting is dealing with the past, where perfect accuracy is possible and required. It therefore seems as if management accounting attempts to make decisions about the future by pre-empting what the accounting will look like should we make a particular decision. In doing so, they are mostly using financial accounting methods and metrics that were designed for accurately recording events rather than for its relevance of making future decisions. It further seems as if the accounting methods, be they financial accounting methods or management accounting methods, do not serve the real goal of the organisation. The following example proves this (and there are many more). We all know that too much inventory is not a good thing. However, if you increase the levels of your finished goods inventory but do not sell them by the end of the financial year, then your profit on the income statement will actually increase. According to GAAP and IFRS, it is a good thing if the profit on the income statement increases, since it will be more attractive to potential investors. In reality, however, you have not made more money - in fact, you have made less. And you have increased your risk of not selling while simultaneously tying up more cash in inventory. But that is only the visible effect. The invisible effects are reduced due date performance, longer lead times, lower quality, less flexibility in serving your markets well, etc.

So how do we reconcile the future and the past? Can we continue using accounting methods for future decision-making? It is not a question of reconciling the future and the past. It requires an understanding of the nature of accounting and the nature of decision-making. This will allow us to make good decisions about the future that will show a positive effect in financial accounting once we start recording the events that have taken place as a result of our previous, good decisions. This will ultimately lead to better achieving the goal. It is about understanding what the cause is, and what the effect is. The effect of our decisions should result in better financial performance. It is for this purpose - i.e., good decision-making to achieve the goal - that Goldratt [1] stresses the importance of appropriate measurements: 
Not just any measurements, but measurements that will enable us to judge the impact of a local decision on the global goal.

Recognising the differences between the future and the past, and understanding the cause-effect relationships, must allow us to derive the correct formulas for NP and ROI and how to consider cash flow that will allow for good decision-making. The bad news is that we must change the way we have been doing it for so long. The good news is that we will be simplifying the decision-making considerably by including only what is relevant to the decision - a principle with which the management accountants already agree.

Having the right measurements to predict the impact of your decisions on goal achievement is one side of the coin. The other side of the coin is to make sure that those measurements are in line with the system principles governing how systems, including organisations, behave. It is exactly here where Cooper and Kaplan [4] make a fundamental mistake by stating the following:

To discover which actions will increase selling margins and reduce operating expenses, managers need to understand patterns of resource consumption at the micro level, where the action is really taking place.

Systems are not about the components, but about the relationships between all the parts and how they function together. Jackson [12] describes holism (i.e., systems) in the following way:

Holism puts the study of wholes before the parts. It does not try to break down organizations into parts in order to understand them and intervene in them. It concentrates its attention instead at the organizational level and on ensuring that the parts are functioning and are related properly together so that they serve the purposes of the whole.

This is exactly the opposite of what Cooper and Kaplan [4] attempt with ABC. It is therefore necessary to derive a new set of decision-making measurements for NP and ROI that will simultaneously indicate the impact of the decision on cash flow. In its simplest form, net profit is the difference between all revenues minus all expenses or costs. ROI would then be the ratio between the NP calculated (as described in Equation 1) and the investment made. Cash flow will be considered when real money leaves or enters the business. Without having an extensive discussion, which would just be a replication of Goldratt [1] (see pages 14-51), the basic NP equation can be presented as:

$$
\begin{aligned}
& N P=\Sigma V o l_{i}\left(S P_{i}-V C_{i}\right)-\Sigma F C_{n} \\
& \text { where } \\
& N P=\text { Net profit/ time period } \\
& S P=\text { Selling price per unit } \\
& V o l=\text { Volume of units sold per time period } \\
& V C=\text { Variable cost per unit } \\
& F C=\text { Fixed cost per time period } \\
& i=1,2,3, \ldots . . . i \text { (Revenue from products and/or services and other revenue streams) } \\
& n=1,2,3, \ldots . . . . n \text { (FC categories) }
\end{aligned}
$$

The way systems thinking is incorporated into the equation is to consider that the volume produced and sold is determined by the constraint capacity only, irrespective of whether it is an internal constraint or a market constraint. The value of the volume produced but not sold will be equal to the volume produced but not sold multiplied by the variable cost only, and then to be considered part of investment. No fixed costs will be allocated to unsold products, since the fixed costs would be considered in the equation as a total for the time period. Only real, relevant costs will be included for decisions (e.g., depreciation is not real, nor relevant, therefore ignored for any decision). Also, no cost allocation takes place, which overcomes the two major problems from traditional cost allocation: (1) the complaints that cost allocation is unfair and inaccurate; and (2) where the fixed costs of unutilised capacity be allocated.

\subsection{Applying the measurements to the adapted "PQ" problem}

In this section, the net profit equation derived preciously will be applied to the adapted "PQ" problem using both the traditional/activity-based costing $(A B C)$ way and the systems thinking approach, to be able to compare results. As we have seen in Table 4, the ABC approach favours 
Product $\mathrm{Y}$, whereas the systems thinking way favours Product $\mathrm{X}$, as seen in Table 7 . The company profits calculated for each approach are shown in Table 8 . Since the constraint determines the actual volume produced and sold, only the constraint capacity needs to be considered.

Table 8: Mix and net profits for each of the two approaches

\begin{tabular}{|l|l|}
\hline \multicolumn{1}{|c|}{ ABC approach } & \multicolumn{1}{c|}{ Systems thinking approach } \\
\hline Favours Product $\mathrm{Y}$ based on cost per unit & Favours Product $\mathrm{X}$ based on throughput rate \\
\hline Maximise $\mathrm{Y}=60$ & Maximise $\mathrm{X}=60$ \\
$\mathrm{~B}: 15 \mathrm{X}+60(30)=2400$ & $\mathrm{~B}: 60(15)+30 \mathrm{Y}=2400$ \\
$\mathrm{X}=40$ & $\mathrm{Y}=50$ \\
\hline $\mathrm{NP}=\Sigma \mathrm{Vol}_{\mathrm{i}}\left(\mathrm{SP}_{\mathrm{i}}-\mathrm{VC}_{\mathrm{i}}\right)-\Sigma \mathrm{FC}_{\mathrm{n}}$ & $\mathrm{NP}=\Sigma \mathrm{Vol}_{i}\left(\mathrm{SP}_{\mathrm{i}}-\mathrm{VC}_{\mathrm{i}}\right)-\Sigma \mathrm{FC}_{\mathrm{n}}$ \\
$\mathrm{NP}=40(95-45)+60(105-40)-6000$ & $\mathrm{NP}=60(95-45)+50(105-40)-6000$ \\
$=-\mathrm{R} 100 /$ week & $=\mathrm{R} 250 /$ week \\
\hline
\end{tabular}

The systems thinking approach provides a far better answer than the $A B C$ approach when utilising the existing scarce system resources well. In both cases, the constraint (Resource B) is utilised 100 per cent of the time. It is also clear that the fixed cost is irrelevant for the mix decision since, irrespective of which mix is selected, the fixed cost remains at R6 000 per week. When the ABC approach allocates the fixed cost, it suggests that the fixed cost varies on the basis of product diversity, product volume, and complexity of the operations, which is a fundamental logical thinking error made by Cooper and Kaplan [4] and Gupta and Baxendale [5].

If the two proposals are analysed using the derived net profit formula, without making any calculations, it is clear that Proposal 2 should not get any further consideration. If Proposal 2 were to be implemented, the fixed cost would show a once-off increase of R3 000 , the variable cost for both products would stay the same, the selling prices for both would stay the same, as well as the volume sold. Since the constraint determines the volume sold, and since Proposal 2 does not address the constraint (resource $B$ ), not a single unit more will be produced and sold. The net effect will be a reduction in profit, a reduction in ROI, and reduced cash flow. This is despite the fact that, in Table 5, it is suggested that the profit for each of the products will increase with the implementation of Proposal 2. The product profit increase is an illusion: it is not real.

In Table 9 the calculations are shown for analysing Proposal 1. This proposal will be considered, since it reduces the process time on the constraint, albeit a very small reduction.

Table 9: Effects of Proposal 1 implementation on the financial measurements using the systems approach

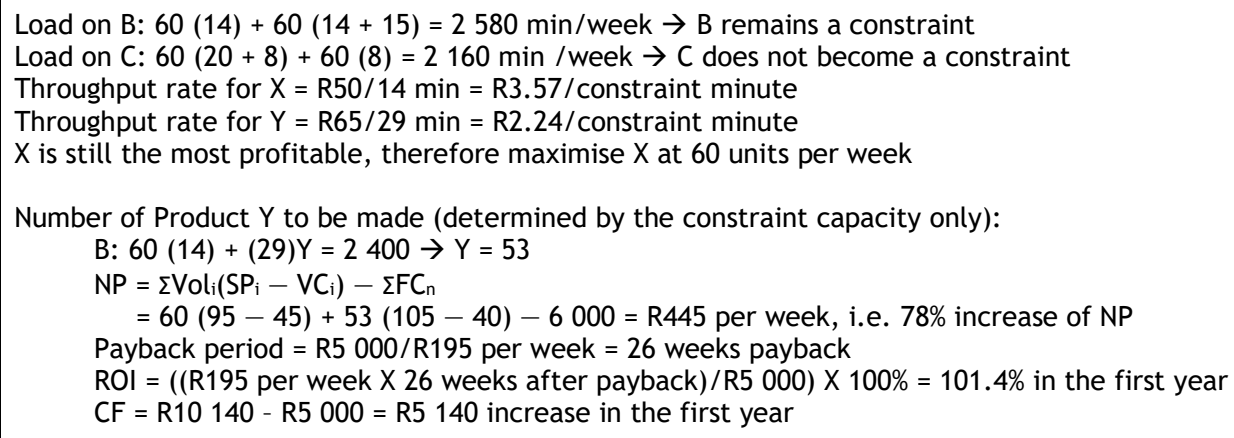

\subsection{Arguments against the $A B C$ approach and for the systems thinking approach}

The question now arises why the costing approach fails to give good answers, and why the systems thinking approach provides superior answers. It all boils down to a simple mathematical principle. One must make sure that measurements used on a lower level are the same as, and are directly related to, the higher-level measurement they want to influence. Looking at the cost approach, the deep truth, as defined by Smith and Smith [3]:

....assumes that return on investment (ROI) is maximized through and directly corresponds to the minimization of unit cost. 
Since ROI is dependent on net profit, one can restate the assumption, as net profit is maximised and directly corresponds with the minimisation of unit costs. In other words, net profit goes up when cost per unit goes down, and net profit goes down when cost per unit goes up. It further follows that profit per unit equals the selling price per unit minus the cost per unit (calculated using activitybased costing, and demonstrated by Gupta and Baxendale [5]). Therefore, if profit per unit goes up, profit for the company goes up, and if profit per unit goes down, profit for the company goes down.

This is exactly where the problem lies with the $A B C$ approach. Costs and profit for the products are calculated on a per unit basis, whereas profit for the company is calculated on a per time basis (see Equation 1). Mathematically it can be expressed as shown in Table 10.

Table 10: Assumed proportional relationship between company and product profitability

\begin{tabular}{|c|c|}
\hline Profit of the company measurement & Profit of the product measurement \\
\hline$\frac{\text { Rand profit }}{\text { Time }^{1}}$ & $\frac{\text { Rand profit }}{\text { Unit }^{2}}$ \\
\hline
\end{tabular}

${ }^{2}$ Capacity time based

Since we have Rand profit above the line for both measurements, it follows that, for these two equations to be directly proportional, Time and Unit must therefore be the same. They obviously are not. Two attempts might be made to prove this relationship to be correct. The first is to argue that profit per unit is derived from cost per unit, which is based on time. The problem with this argument is that the time used for cost per unit calculation considers all processing time, irrespective of the processes needed to produce a product run in parallel or in series. In other words, this time calculation is based on capacity required or work content. The profit for the company, on the other hand, is calculated using elapsed time or a period time - i.e., no parallel times are included. Since the basis for the timing is different, the argument falls flat: capacity time and period time are totally different. The second attempt to prove this relationship to be correct is to multiply the Rand profit per unit by the number of units sold per period of time, as shown in Table 11. In doing so, the units will cancel out, also leaving Rand profit per time. The same logic is applied to refute this claim. Since units sold per time is a period time, and the Rand profit per unit is calculated using capacity time, this logic is also false. What makes it even worse is the fact that unutilised and therefore unallocated fixed costs are ignored. Apart from the logical mistake, the equation in Table 11 cannot be related to Equation 1.

Table 11: Assumed proportional relationship between company and product profitability

\begin{tabular}{|c|c|c|}
\hline Profit of the company measurement & Profit of the $p$ & surement \\
\hline$\frac{\text { Rand profit }}{\text { Time }^{1}}$ & $\frac{\text { Rand profit }}{\text { Unit }^{2}}$ & $\frac{\text { Units }}{\text { Time }^{1}}$ \\
\hline
\end{tabular}

The systems thinking approach does not suffer from these problems. Since the throughput rate is calculated as Rand profit per constraint time when an internal constraint exists (the contribution margin is the profit per unit), and since the capacity of the constraint, a single resource, is equal to the time over which the company profit is measured, this confirms that we are dealing with the same time measurement. This relationship is shown in Table 12 and can be related to Equation 1.

Table 12: Proportional relationship between throughput rate and company profit when an internal constraint exists using the systems approach

\begin{tabular}{|c|c|}
\hline $\begin{array}{c}\text { Profit of the company } \\
\text { measurement }\end{array}$ & Profit of the product measurement \\
\hline$\frac{\text { Rand profit }}{\text { Time }^{1}}$ & $\propto\left(\frac{\text { Contribution margin }}{\text { Constraint time }^{1}} \times \frac{\text { Constraint time }^{1}}{\text { Unit }} \mathrm{X} \frac{\text { Units }^{2}}{\text { Time }^{2}}\right)-\frac{\text { Fixed costs }^{\text {Time }^{1}}}{}$ \\
\hline
\end{tabular}

${ }_{1}^{1}$ Period time based

2 Units per time is determined by constraint capacity per period time 
When we have a market constraint, the contribution margin is still considered as profit per unit; but this time the profit per unit is not calculated on a time basis. If the profit per unit (i.e. contribution margin) is now multiplied by volume sold over a period of time (determined by the market constraint), we end up with period time only. This is shown in Table 13 and can be related to Equation 1.

Table 13: Proportional relationship between throughput rate and company profit when a market constraint exists using the systems approach

\begin{tabular}{|c|c|c|c|}
\hline $\begin{array}{l}\text { Profit of the company } \\
\text { measurement }\end{array}$ & \multicolumn{3}{|c|}{ Profit of the product measurement } \\
\hline$\frac{\text { Rand profit }}{\text { Time }^{1}}$ & $\left(\frac{\text { Rand profit }}{}{ }^{1}\right.$ & $\left.\frac{\text { Units }^{2}}{\text { Time }}\right)$ & $\frac{\text { Fixed costs }}{\text { Time }^{3}}$ \\
\hline
\end{tabular}

It can now be concluded that $A B C$ suffers from two more major problems that have been exposed by this paper. The first is that it ignores the existence of a constraint (internal or market). It treats all resources as equal as far as profitability is concerned. Systems thinking is clear on the fact that the constraint determines the profitability of the company. The second major problem is that the foundation of cost allocation is capacity time, while the net profit of the company is based on period time. As stated previously, it is a well-known fact that $A B C$ suffers from two further and still unsolved problems: its inability to allocate costs fairly and accurately, along with the problem of where to allocate unutilised capacity. Suffering from these four major problems clearly makes $A B C$ unsuitable for any decision-making, since it does not consider the systemic nature of business.

Despite its failure, some authors still insist on its applicability for sound decision-making. Gupta and Baxendale [5] do their utmost to 'make ABC look good'. In order to do so, they adjust the numbers of the "PQ" problem to suit their agenda. They choose the fixed cost for the different resources, so that the constraint resource has the highest fixed cost. Since Product $X$ uses the least amount of constraint time, very little of this very expensive resource is allocated to Product $X$, making it the most profitable - i.e., it would give the same answer as when the throughput rate method was used. Based on this, they conclude that $A B C$ is a sound method for product prioritising when an internal constraint exists. Even though Product $Y$ ends up selling for less than its unit cost - i.e., at a loss - they suggest to continue to sell it, which does not make sense at all. Since fixed cost is irrelevant to the mix decision, if the total fixed cost and other variables (e.g. demand and variable costs per unit) for the adapted "PQ" problem stay the same, Product X will always be the most profitable product, since it generates contribution margin the fastest, considering its constraint time. If $A B C$ is such a sound method, it should always give the correct answer - i.e., maximum profit - irrespective of how the fixed costs are split among the resources. When fixed costs are equal as in the adapted "PQ" problem, $A B C$ gives a different and wrong answer, seen in Tables 4 and 8 . It will also suggest the wrong proposal to implement, seen in Table 5 and explained in the discussion, based on improved unit profit/reduced unit cost. Systems thinking will always give the same correct answer, irrespective of how the fixed cost is split among the resources. Pushing the agenda of $A B C$ is not only fundamentally wrong. It is outright irresponsible.

\section{CONCLUSION}

We are entering an era of big technological advancements and huge possibilities. The fourth industrial revolution has many of us very excited. For industrial engineers and the profession, many new doors of opportunities are, and will be, opened. By virtue of our training and way of thinking, industrial engineering as a discipline is well-positioned and well-suited to help face the challenges and to capitalise on the opportunities with which the fourth industrial revolution is presenting us. It is important, however, that a clear distinction is made between business issues and technological issues. Any improvement is a change, but not all changes are necessarily an improvement. It is therefore of the utmost importance to approach organisational performance improvement from a systems and business perspective. The most important question one needs to ask is, "Where is the constraint?" Only when the constraint is improved will significant benefits be seen, and only then will improvements be of great value. In addition, the correct measurements and methods must be used to make appropriate decisions. Introducing new technologies in a non-systemic way might 
improve efficiencies at a local level, but it might have absolutely zero impact at the system level. Taking the systems approach to organisational decision-making is a real alternative without which alternative realities will remain merely a dream.

\section{REFERENCES}

[1] Goldratt, E.M. 1990. The Haystack Syndrome. New York: North River Press.

[2] Drucker, P. 1964. Managing for Results. New York: Harper Business.

[3] Smith, D. \& Smith, C. 2014. Demand driven performance - Using smart metrics. New York: McGraw-Hill Education.

[4] Cooper, R. \& Kaplan, R.S. 1991. Profit priorities from Activity-Based Costing. Harvard Business Review, 69(3), pp. $130-135$

[5] Gupta, M. \& Baxendale, S. 2008. The enabling role of ABC Systems in Operations Management. Cost Accounting, 22(5), pp. 5 - 17.

[6] Pretorius, P.J. 2004. Long term decision-making using throughput accounting. Transactions of the IEEE Africon Conference 2004. 15 - 17 September. Gabarone International Conference Centre, Botswana, pp. $861-866$.

[7] Pretorius, P.J. 2004. Getting back to basics: Productivity revisited. Transactions of the IEEE International Engineering Management Conference 2004. 18 - 21 October. Pan Pacific Hotel, Singapore, pp. 1284 1288

[8] Noreen, E.W., Smith, D. \& Mackey, J.T. 1995. The Theory of Constraints and its implications for Management Accounting. New York: North River Press.

[9] Horngren, C.T. 1981. Introduction to management accounting. $5^{\text {th }}$ ed. London: Prentice/Hall International.

[10] Drury, C. 2013. Management accounting for business. $4^{\text {th }}$ ed. Hampshire: SOUTH-WESTERN CENGAGE Learning.

[11] Unknown. n.d. Accrual Accounting Concept in IFRS and GAAP. Available from: www.financetrain.com/accrual-accounting-concept-in-ifrs-and-gaap/ (Accessed 18 August 2019)

[12] Jackson, M.C. 2003. Systems Thinking: Creative Holism for Managers. West Sussex: John Wiley \& Sons. 